PLANTS PEOPLE

POSSIBILITIES

\title{
Encephalartos Hildebrandtii
}

\section{Author(s): O. Stapf}

Source: Bulletin of Miscellaneous Information (Royal Botanic Gardens, Kew), Vol. 1914, No. 10 (1914), pp. 386-392

Published by: Springer on behalf of Royal Botanic Gardens, Kew Stable URL: http://www.jstor.org/stable/4119545

Accessed: 27-06-2016 02:34 UTC

Your use of the JSTOR archive indicates your acceptance of the Terms \& Conditions of Use, available at

http://about.jstor.org/terms

JSTOR is a not-for-profit service that helps scholars, researchers, and students discover, use, and build upon a wide range of content in a trusted digital archive. We use information technology and tools to increase productivity and facilitate new forms of scholarship. For more information about JSTOR, please contact support@jstor.org.

Royal Botanic Gardens, Kew, Springer are collaborating with JSTOR to digitize, preserve and extend access to Bulletin of Miscellaneous Information (Royal Botanic Gardens, Kew) 
are $\frac{1}{6}$ in. long, whitish becoming pale brown, usually gland-tipped. Leaves oblong-lanceolate, acuminate, cuneate to slightly auricled at the base, 3 to 6 in. long, $\frac{3}{4}$ to $1 \frac{1}{2}$ in. wide, setose beneath, especially on the midrib; petiole $\frac{1}{4}$ to $\frac{5}{8}$ in. long. Flowers borne in trusses 4 in. wide, corolla campanulate, $1 \frac{1}{2}$ in. in length and width, rich red in the typical form, but said by Wilson to vary in colour from crimson to white. The stamens are ten, their filaments glabrous. The calyx, peduncle and fruit are all bristly, the last-named $\frac{1}{2}$ to 1 in. long, cylindrical.

$R$. strigillosum is evidently closely allied to $R$. pachytrichum, but its leaves are of different shape and more hairy beneath, and the glabrous filaments give a ready distinction. It was discovered by David and named as long ago as 1886, but was introduced about ten years ago by Wilson. Like $R$. pachytrichum it is liable to have its young shoots injured by late spring frosts. We shall probably see it at its best in the Cornish gardens.

\section{LXXII.-ENCEPHALARTOS HILDEBRANDTII.}

\section{O. STAPF.}

A proposal to publish illustrations of Encephalartos Hildebrandtii in the Botanical Magazine has necessitated a revision of the existing material of that plant in the Gardens, Museums and Herbarium at $\mathrm{Kew}$ as well as of the relative literature. In the course of the work some new facts worthy of record have come to light with regard to the history of the discovery of the plant, its distribution in East Africa and certain points of physiological interest. To a great exteut they are based on observations recorded in the voluminous correspondence which Sir John Kirk carried on with Sir Joseph Hooker, and with Sir W. T. ThistletonDyer, whilst acting as Consul-General in Zanzibar. These observations constitute a valuable contribution to our knowledge of an interesting plant; their publication may serve as one more acknowledgment of Sir John Kirk's work as a keen naturalist, active observer and ever ready friend of Kew.

Discovery and Distribution.-On March 20th, 1868, Kirk announced to Sir Joseph Hooker the discovery of a new Encephalartos at Dar es Salam of which he had secured an entire plant. At the same time he sent home some pinnae of a leaf and some seeds. A cone, which was to have keen brought home by the Rev. Mr. Wakefield, never reached its destination. The pinnae and the seeds which are still preserved in the Museum were, of course, insufficient for description. In $1870 \mathrm{a}$ " root" followed, but altholigh its receipt is duly recorded, it cannot any longer be traced and probably was found to be dead. Another plant forwarded that year seems to have had the same fate; but seeds received in September, 1870, germinated, and at least one of the plants thus raised is still alive. Long before the plants at Kew were large enough to be described, the species was rediscovered by the German traveller and collector, J. M. Hildebrandt, and was sent to Berlin and subsequently distributed in numerous specimens to various European gardens. The speci- 
mens received at Berlin, imperfect as they were, were described at once by Professor Alexander Brạun and the Curator of the Berlin Botanic Garden, C. Bouché, and named after Hildebrandt. This was in 1874.* Subsequently when the plants had recovered from the journey and been supplemented by further material, more complete accounts were published by A. Braunt and Professor Eichler.+ It is not exactly known where Hildebrandt collected his first specimens, and Braun and Bouché merely define the area of the species as covering " the coast of Zanzibar and to the north as far as Mombasa." In 1877 Kirk made a rapid journey to the outer Usambara Hills, opposite the island of Pemba, when he wrote (October 12th) to Sir Joseph Hooker: "The country on the march from the coast to the hills was like the maritime region of East Africa generally, the chief points of interest being the Pandanus of a species I do not recognise and the Encephalartos I sent you seeds of .... I had imagined this Encephalartos to be beyond, rather to the mountains. I see at Tanga that it is rather native of the maritime plains, elevation from 200-500 feet only, on coral metamorphic limestone." Hildebrandt had meanwhile made several expeditions to Mombasa, and in his narrative, $\$$ published in 18\%9, he stated that (in 1876) he found the hills (Jurassic limestone) near Shangamue, that is, betreen the Durum hills and the Fimboni Valley, about 12 miles N.W. of Mombasa, covered with short grass and Acacias and scattered plants of Encephalartos Hildebrandtii. "Their shining stems," he says, "rise to $5 \mathrm{~m}$. The wide spreading, dark green crown of mucronate fronds protects the large fruiting cones, the farinaceous seeds of which serve as food in times of famine." The most striking plant associated with it in that region is the Borassus palm, whose columnar trunks attain double the height of the Encephalartos. In $1878 \mathrm{Kirk}$ at last succeeded in sending home a male stem in good condition, 1 foot thick and 3 feet long, measuring with its fronds 12 feet. It came from Tanga, or from some point on the coast opposite Pemba. This specimen is still in vigorous health, the stem measuring $1 \mathrm{~m}$. in height and $0.37 \mathrm{~m}$. in diameter, whilst the fronds rise to $2.4 \mathrm{~m}$. above it, being up to $2.25 \mathrm{~m}$. long. At the same time he mentioned having been told of stems as much as 12 to 14 feet high, and in a later letter he speaks of having seen one 20 feet high and of great thickness, adding " it will cost a little to get them here and send them thence. I shall have to hire a native vessel and lower them with ropes, and it will require, I should say, fifteen or twenty men to each one, they are so thick and heavy." "This giant he saw when at the north end of the island. Some months later (February, 1879) he returned there, and this is the account he gives of the singular condition under which the Encephalartos grows, illustrating it by a photograph of a whole plant in its habitat and another of the male and female cones collected on that

* Encephalartos Hildebrandtii, A. Braun \& Bouché, Ind. Sem. Hort. Berol. (1874) 8 .

+A. Braun in Sitz. Ber. Gesellsch. Naturf. Freund., 1876, Oct. 17.

\pm Eichler in Monatschr. Ver. Beförd. Gartenhau, xxiii. (1880) 50.

$\$$ Proceed. Geogr. Soc. xxii. 449, and Engl. Pflanzenwelt Ost.-Afr. I. A. 173. 
occasion: "I have returned from visiting the north coast of this island (Zanzibar) with a view to sending to Kew one of the large Cycads (Ercephalartos) I before told you of. Captain Earl, of H.M.S. "Linden," took me in a steam launch. We saw the trees standing out in the rocky shore, but had difficulty in effecting a landing, although it was at the time calm. The raised coral rock here stands $25 \mathrm{ft}$. above the sea, and is hollowed out to lean so that only at a chance spot was it possible to climb up, and then we were forced to use ropes. Once on the top it was equally difficult to move along, for near the coast the coral had been corroded into a number of spikes with sharp angles and eavities, into which it would have been most dangerous to slip. Farther inland these hollows were partially filled with red earth, so that it was easier to move about, but to transport a tree even of less size than those we had come in quest of, was clearly impossible with the means at our disposal over such dangerous and impracticable ground. We therefore selected one with a trunk 15 feet high clear of leaves, a male in full flower and with a crown of leaves that raised it 22 feet from the ground. This grew on the edge of the rock, so that we would not have to carry it over the spikes. It was soon found impossible, however, to take it off the roots, as these had filled every crevice of the rock holes. We cut it, therefore, off the rock, securing quite enough to enable it to grow without difficulty. Most unfortunately when the work was almost done it fell and snapped asunder on a rock, one-third from the top. The lower part we, however, took on board, and I have planted it on the chance that it may shoot out, as I saw many old trunks had done. After this we secured with great labour a small plant that had not yet flowered. The stem of this is about 5 feet high. This also I have planted here to give it a better chance of standing the voyage. I took a photo of a female tree 5 feet high in fruit. I have also taken one of the male and female cones which I sent. I also enclose a photo of the male and female cones of the Mombasa plant. The female cone in that is, however, unusually short. I hope the photos will be of some use as a guide. I am not sure that I shall have the full view of the Encephalartos in fruit printed in time to send now. It has a very peculiar habit.... to that of the other Cycads, and the many fruits set at an angle are peculiar. The Encephalartos of the place we went to is singularly limited to those rocks. The country a few hundred yards back is open grass, but there not a specimen is seen. These rocky places contain many peculiar plants besides. I saw Dorstenia, an Impatiens and other plants, including the Calumba root that seemed to stand and enjoy the heat, the drought and the hard limestone rock. When next I go there it must be with better appliances and more time at my disposal. There must be the means of getting a mass of trunk a ton weight, over the sharp rocks without cutting the men." Yet no opportunity for repeating the expedition to those limestone cliffs secms to have arisen, and the Encephalartos inhabiting them remained undisturbed. Meanwhile Kirk had planted Enceph- 
alartos Hildebrandtii in his country garden* on the Island of 'Zanzibar, with the intention of having a "Cycad avenue," and it was thence, in 1884, that he sent to Kew the fine male and female specimens, from which the two plates, which are shortly to appear in the Botanical Magazine, were prepared. The correspondence on Enccphalartos Hildebrandtii ceased with the letters advising the despatch of those stems.

Since then. Encephalartos Hildebrandtii has been found to extend in Usambara as far inland as the upper Bombo Valley (45 miles from Tangá), so that Dr. Kirk's original surmise that it should $€ x$ tend "beyond rather to the mountains" was after all justified. Here, as wel! as in the drier parts of the littoral, it is associated with the candelabra-like Euphorbia Nyikae, Sansevieria guineensis, and an unnamed Aloe. Other recent records are from Rossako, $†$ about 17 miles west of Bagamoyo and from the west coast of Zanzibar Island. Werth+ alludes to it as a characteristic element of the bush formation of the young coral land of Zanzibar Island, "nowhere appearing in masses, but always in scattered individuals or small groups, in a short stem bearing wide dense crowis of spinous fronds." The area of this Cycad is therefore, as far as we know at present, confined to a narrow belt on the coast of East Africa, extending over about 200 miles from Dar es Salam to Mombasa. Within this belt the ground should be mostly limestone, either Jurassic or of young coral formations, and only where the belt attains to its greatest width, namely, in Usambara, would it be formed by gneiss or crystalline schists.

Generation of Heat in the Male Cones.-The fact that heat is generated in the male cones of certain cycads has been known for a long time. Teysman observed it in Cycas circinalis in $1849 \S$ and Jul. Poisson in Dioon edule in 1878. ll Subsequently extensive and accurate records were obtained in 1894 by Professor Gregor Kraus from Ceratozamia longifolia and Macrozamia Miquelii in Buitenzorg. In this connection it is interesting to note that Kirk had also observed the same phenomenon in Encephalartos Hildebrandtii in 1878 , reccrding on one occasion a rise of temperature

* Sir John Kirk, to whom we have submitted this article, sends as the following letter with reference especially to his garden at Zanzibar :-

December 7th, 1914.

"It seems strange to go back and find extracts from my letters of many years agn still of use. I was not aware that Sir Joseph Hooker had kept my correspondence. I wish I had preserved the many letters he wrote me but papers soon get lost in the tropics amongst the many other interests that had to be attended to . . . In my experimental garden on the Island of Zanzibar . . . I had a wonderful collection of shrubs, trees and flowering plants which $[$ acquired in exchange from many sources, India, Australia, as well as from England, and to this day that garden covering 40 acres still remains and the lofty Eucalyptus trees of several species, including the citriodora. the Mahogany tree, the Para and Ceara rubbers, the Brazil nut, etc., and all that flourish well are well cared for by Miss Thackeray who took the place over from me."

+ Stublmann, Mit Emin Pascha, p. 824.

\pm Werth, Die Vegetation d. Insel Sansibar (Diss. 1901) 49.

$\$$ Nederl. Kruidkund. Archief. i. (1850) pp. 109-114; ii. (1851) pp. 18:3-184.

I| Bull. Soc. Bot. France, xxv. (1878) pp. 253-254.

T! Annal. du Jard. Bot. Buitenzorg, xiii. (1896) pp. 217-25l. 
of as much as $16 \cdot 5^{\circ} \mathrm{F} .\left(9 \cdot 15^{\circ} \mathrm{C}\right.$. $)$. This is what he said in writing to Kew on January 6th and 31st:-

January 6th._. 1 have in my garden a plant of Encephalartos Hildebrandtii now in male cone. There are six cones close together in the crown, and last night when walking home with two in ny hand, I noticed a strange fact worth noting and following up, both in this and other species. The cones were in paper-I had them in a bag, the sun had set, and there was nothing to disturb the temperature, but on taking them out to show some friends at home, I found them very hot. I placed them in a cloth with a thermometer that reached outside; the air was then $81.5^{\circ}$, and soon the cones rose to $98^{\circ}$, being $16.5^{\circ}$ above the air. I left them there all night, and although they had becn at an open window and exposed to the night air, they still were $6^{\circ}$ above the air, which was $80^{\circ}$, while the cones showed $86^{\circ}$. They were then perfecting the pollen, which fell from the scales when shaken. I must try this on the cones when still on the plant, for those I observed with had been separated, but $I$ doubt not this is a remarkable instance of heat generated as in arums at the time of forming the pollen. I have a male $C y c a s$ now coming on, and shall try it in that also.

January 31st.-." I have, since writing on the 6 th inst., verified my observations on the temperature of the male cones of Encephalartos Hildebrandtii. The temperature is highest as the pollen is being matured and when the first can be shaken out. I have also made a practical experiment on the large male conc of our Cycas sp. Unluckily it has been brought to me when ripening the pollen, sothat I have only an indication that the same phenomenon will be found in it. The rise of temperature was distinct. I have been very careful to avoid all chance of error, and this is rendered impossible by the small mass of the cone of Encephalartos, which could not retain solar heat inside and show as if it had originated heat. Besides, in the last stage of my experiment, there had been no sun all day, and the cone was quite cold and rose to its high tempcrature. I daresay all this is well known to you, but I have few works of reference here."

Encephalartos Hildebrandtii and E. villosus.-Shortly after the publication of the first description of Encephalartos Hildebrandtii by A. Braun and Bouché, the validity of the species was questioned by F. Regel, ${ }^{*}$ and its identity with Lehmann"s E. villosus, a native of Natal, suggested. "No reasons for this reduction were then stated, beyond that "the fronds of more luxuriant specimens seen at Berlin, Cologne and Brussels pass into those of E. villosus.", A. Braun replied to E. Regel's criticism the same rear, $\dagger$ pointing out the differences in the vegetative structure and in the female cones. According to him the stems of $E$. villosus are relatively stouter than those of $E$. Hildebrandtii, the petioles are thrown off earlier, so that the trunk appears armed by their persistent bases close up to the crown, the leaves are less hard and pungent, the teeth of the pinnae (4-9 on

* In Gartenflora (1876), p. 204.

† A. Braun in Sitz. Ber. Gesellsch. Naturf. Freund. (1876), pp. 118-123. 
each sirle, most frequently j-6) more numerous, more distant near the base and more approximate towards the apex, pointing straight forward or spreading at a very acute angle. The head of the female scales, that is the portion of the scale which alone is visible in the entire cone and forms its surface, is in E. Hildebrandtii rhombic in outline, comparable to the apophysis of a cone scale of Pinus, sect. Pinea, with the hexagonal umbo rather lower down than in the conifer, whilst in $E$. villosus it is, although also rhombic, quite destitute of an "umbo"; to this may be added that in $E$. Hildebrandtii straight ridges radiate from the points of the umbo, whilst in $E$. villosus a downward curving transverse line divides the apophysis into a convex large upper field, lying in the plain of the surface of the cone and a smaller lower field sharply receding towards the axis; this line is, moreover, produced into a cartilaginous, toothed crest. A few years later Braun's differentiation was confirmed by Eichler, ${ }^{*}$ who was able to study the structure of the female cone on living material, one of the specimens received from Hildebrandt having at last produced flowers. Since then the two species have once more been declared by $P$. Henningst to be identical. Hennings had observed in a nursery near Berlin a flowering female specimen of an Encephalartos which had been grown for years as $E$. villosus and appeared to be an intermediate between this and $E$. Hildebrandtii. According to Hennings, the intermediate character manifested itself in the pinnae, as rell as in the cone scales. To illustrate his view he figures one pinna of typical $E$. villosus, one of the intermediate form and a number of pinnae of $E$. Hildebrandtii. This, however, seems hardly convincing, when regard is had to the circumstance that each frond possesses well over 100 pinnae, which not only vary according to the age and the vigour of the plant, but vary also within the same frond, according to their position on the common rhachis. This being so, it is not difficult to pick out pinnae, which in shape are intermediate between those described as typical for either species. But taking the fronds as a whole, as they are represented by a number of living plants and of dried samples at Kew, I should say that A. Braun's differentiation is quite correct, except in so far as it relates to the leaves of young plants of $E$. Hildebrandtii-I have in mind a leaf of a ten-year-old plant raised from seed communicated by Dr. Kirk, which seems to resemble that of $E$. villosus, particularly in the shape, orientation and arrangement of the teeth. But placing adult plants side by side, there should be no difficulty in distinguishing the two species, even in the absence of female cones. In E. Hildebrandtii the fronds are bcrne on a cylindric, often much elongated stem, they are very rigid, their wool disappears early or is from the outset only moderately copious, their pinnae are very firm, those of the middle or just above the middle of the front are about 9-10 times as long as wide, the teeth usually are $3-4$ in number on each side, are rigid, somewhat spreading with the uppermost usually distant from the apex. In $E$. villosus, on the other hand, the

* Eichler in Monatschrift. d. Verein. z. Beförd. d. Gartenbau. xxiii. (1880), pp. 50-54, tab. 1.

† Hennings in Gartenflora, xxxix. (1890), pp. 234-238, with Abbild. 55. 
fronds are borne on a short subglobose trunk, they are less rigid than in E. Hildebrandtii, their wool is more copious and persists longer, their pinnae are thinner, those of the middle of the frond are about $13-15$ times as long as broad, the teeth are usually 4 in number on each side, with the upper ones close to the apex or they are almost absent, ther are less rigid than in $E$. Hildebrandtii, and distinctly directed forward so as to be often parallel to the midrib of the pinna. As to the female cones the differences, as far as I can judge from the dried and spirit material at Kew and from drawings and photographs made at different times, are quite conspicuous and constant. "It is true the toothing and crenulation of the transverse ridge of the apophysis of $E$. villosus may be obscure in some scales and the convex portion above this ridge may become flattiened where it rises highest, the head of the scale assuming the shape figured by Hennings l.c. Abb. 55, fig. 2a; but these modifications are confined to the portions of the cone near one or the other end (the scale figured by Hennings was taken from the upper nart) where the scales are generally reduced, or so modified as to lose somewhat of their characteristic appearance. In any case such flattened scales of $E$. villosus, with their entire trausverse ridge, are still very different from those of $E$. Hildebrandtii with their polygonal umbo and the straight ridges radiating cut from its corners, a character not sufficiently emphasized by Hennirigs' fig. 1.

It may finally be added that the male and female cones of $E$. Hildebrandtii vary considerably in size, and especially in length, and the male occasionally also in colour, so much so that Dr. Kirk was for some time doubtful whether there were not two species on the East coast of Africa; but in the end he came to the conclusion that this was not so, and the examination of the Kew material certainly supports this view. Both suspected forms are represented by living males at Kew, one producing cones up to $42 \mathrm{~cm}$. by $10 \mathrm{~cm}$. with greenish-brown apophyses and pale brick-red claws, the other bearing cones not much over $20 \mathrm{~cm}$. long and $6 \mathrm{~cm}$. in diameter and brick-red all over. Apart from these dimensions and colour differences, there is nothing in the plants to allow of discrimination.

\section{IXXIII.-MISCELLANEOUS NOTES.}

Mr. R. A: Rolfe, A.L.S., an Assistant, Second Class, in the Royal Botanic Gardens, Kew, has been promoted to the grade of Assistant, First Class, with effect from November 6 th.

Mordecar Cubirt Cooke.-It is with sincere regret that we have to announce the death, in $\mathrm{k}$ : is ninetieth year, of Dr. M. C. Cooke. Dr. Cooke had charge of the Lower Cryjtogams in the Herbarium from 1880 till 1892, during which time he completely re-arranged the fungi, incorporated large collections, and published the most important of his works, "Illustrations of British Fungi." Extraordinarily industrious he accomplished during his long life an 